\title{
LITERATUR REVIEW KOMBINASI SENAM HIPERTENSI DAN SLOW DEEP BREATHING TERHADAP PENURUNAN TEKANAN DARAH PASIEN HIPERTENSI
}

\author{
Bela Purnama Dewi ${ }^{1}$, Elsa Mayora ${ }^{2}$ \\ Program Studi S-I Ilmu Keperawatan STIKES Mitra Adiguna Palembang \\ Jl. Komplek Kenten Permai Blok J 9-12 Bukit Sangkal Palembang \\ Email : belapurnamadewi@gmail.com
}

\begin{abstract}
Abstrak
Menurut data World Healty Organization (WHO, 2015) menunjukan bahwa jumlah penyandang hipertensi terus meningkat setiap tahun nya, sekitar 1,13 miliar orang di dunia menyandang hipertensi, artinya 1 dari 3 orang di dunia terdiagnosis hipertensi. Diperkirakan tahun 2025 akan ada 1,5 miliar orang terkena hipertensi, dan diperkirakan setiap tahun nya 9,4 juta orang meninggal akibat hipertensi dan komplikasi nya. Pada Penelitian ini menggunakan metode literatur review yaitu adalah serangkaian kegiatan yang berkenaan dengan metode pengumpulan data pustaka, membaca dan mencatat, serta mengelolah bahan penulisan. Peneliti menemukan 14 artikel, kemudian peneliti mereview beberapa artikel yang berkaitan dengan senam hipertensi dan slow deep breathing, Senam dan slow deep breathing diberikan pada pasien hipertensi dengan rata-rata waktu selama 3 minggu, dalam 1 minggu diberikan 3 kali yang berdurasi pada senam 15-30 menit dan slow deep breathing 7-10 menit. Dari artikel-artikel tersebut disimpulkan bahwa pemberian senam dan slow deep breathing pada pasien hipertensi mampu menurunkan tekanan darah.
\end{abstract}

Kata kunci : Hipertensi, senam hipertensi, slow deep breathing, gymnastic,lansia

\begin{abstract}
According to data from the World Health Organization (WHO,2015) shows that the number of people with hypertension continues to increase every year, around 1.13 billion people in the world heve hypertension, meaning that 1 in 3 people in the world are diagnosed with hypertension. It is estimated that in 2025 there will be 1.5 billion people affected by hypertension, and it is estimated that every year 9,4 million people die from hypertension and its complications. In this study using the literature review method is a series of activities relating to the method of collecting library data, reading and recording, and managing writing material. Researchers found 14 articles, then researchers reviewed several articles relating to hypertension and slow deep breathing exercises, gymnastics and slow deep breathing were given to hypertensive patients with an average time of 3 weeks, within 1 week given 3 times which duration of 15-30 minutes and slow deep breathing 7-10 minutes. From these articles it was concluded that the provision of gymnastics and slow deep breathing in hypertensive patients can reduce blood pressure.
\end{abstract}

Keywords : Hypertension, , slow deep breathing, gymnastic, erderly 


\section{PENDAHULUAN}

Hipertensi sering disebut sebagai "The Silent Killer" (pembunuh senyap), karena gejalanya tanpa keluhan. Biasanya, penderita tidak mengetahui kalau dirinya mengidap hipertensi dan baru diketahui setelah terjadi komplikasi. Hal ini lah yang membuat hipertensi menjadi masalah kesehatan dunia yang harus diatasi.

(WHO, 2015) menunjukan bahwa jumlah penyandang hipertensi terus meningkat setiap tahun nya, sekitar 1,13 miliar orang di dunia menyandang hipertensi, artinya 1 dari 3 orang di dunia terdiagnosis hipertensi. Diperkirakan tahun 2025 akan ada 1,5 miliar orang terkena hipertensi, dan diperkirakan setiap tahun nya 9,4 juta orang meninggal akibat hipertensi dan komplikasi nya (KEMENKES, 2018).

Dari data WHO menyatakan bahwa di seluruh dunia terdapat sekitar 972 juta orang atau $26,4 \%$ penghuni bumi menderita hipertensi, angka ini akan meningkat menjadi 29,2\% di tahun 2025. Dari 972 juta penderita hipertensi, 333 juta berada di Negara maju dan 639 sisanya berada di Negara berkembang, termasuk Indonesia. Negara ekonomi berkembang memiliki penderita hipertensi sebesar $40 \%$ sedangkan negara maju hanya $35 \%$ (Widiyani, 2013).

Menurut Kementerian Kesehatan Republik Indonesia mengatakan bahwa hipertensi saat ini sudah menjadi masalah dunia termasuk Indonesia. Indonesia sendiri mencatat terdapat 63.309.620 kasus hipertensi dan menyebabkan kematian sebanyak 427 ribu (KEMENKES, 2016)
Menurut kunjungan Dinas

Kesehatan Kota Palembang, menyatakan dari survei yang di lakukan dibeberapa puskesmas di Palembang di dapatkan data 10 penyakit tidak menular terbesar ditahun 2017 yaitu salah satu nya adalah hipertensi, hipertensi menduduki posisi kedua penyakit terbesar di kota palembang setelah ISPA. (DINKES Kota Palembang,2017)

Penatalaksanaan hipertensi terdiri dari dua yaitu farmakologi dan non farmakologi (Smeltzer and Bare, 2013). Upaya dari segala pihak telah banyak dilakukan dalam mengatasi permasalahan hipertensi. Mulai dari pengobatan farmakologis maupun non-farmakologis.

Terapi farmakologi dilakukan
dengan cara mengkonsumsi obat antihipertensi, menjaga kepatuhan minum obat secara teratur dan sesuai dosis yang di anjurkan. Selain terapi farmakologi, bisa juga dilakukan terapi non farmakologi dengan berbagai cara diantaranya dengan mengatur pola hidup sehat, makan sayur dan buah, diet rendah garam, dan juga melakukan aktivitas seperti berolahraga (senam), latihan nafas dalam (slow deep breathing) dan lain-lain (Tulak, 2017).

Salah satu terapi non farmakologi yang sedang di kembang kan adalah senam hipertensi. Senam hipertensi adalah bagian dari usaha untuk mengurangi berat badan dan mengelola stress yang merupakan dua faktor yang mempertinggi resiko hipertensi (Vitahealth, 2014). Hasil penelitian yang dilakukan Tristyaningsih (2011) menunjukkan adanya penurunan tekanan darah setelah melakukan senam hipertensi. Olahraga (senam) dapat meningkatkan curah jantung yang akan disertai 
meningkatnya distribusi oksigen ke bagian tubuh yang membutuhkan, sedangkan pada bagian-bagian yang kurang memerlukan oksigen akan terjadi vasokonstriksi, misalnya traktus digestivus. Meningkatnya curah jantung pasti akan berpengaruh terhadap tekanan darah (Safitri, 2017).

Slow deep breathing termasuk ke dalam salah satu metode relaksasi. Pada saat relaksasi terjadi perpanjangan serabut otot, menurunnya pengiriman implus saraf ke otak, menurunnya aktivitas otak, dan fungsi tubuh yang lain, krakteristik dari respon relaksasi ditandai oleh menurunnya denyut nadi, jumlah pernafasan dan penurunan tekanan darah (Potter \& Perry, 2006). Penelitian mengenai slow deep breathing yang dilakukan oleh Critchley et al., (2015) dari penelitian tersebut di dapatkan hasil bahwa slow deep breathing mempunyai pengaruh terhaadap penurunan tekanan darah pada pasien hipertensi (Yanti, 2016).

\section{METODE PENELITIAN}

Penelitian ini merupakan penelitian dengan menggunakan metode studi kepustakaan atau literatur review. Literatur review merupakan ikhtisar komprehensif tentang penelitian yang sudah dilakukan mengenai topik yang spesifik untuk menunjukkan kepada pembaca apa yang sudah diketahui tentang topik tersebut dan apa yang belum diketahui, untuk mencari rasional dari penelitian yang sudah dilakukan atau untuk ide penelitian selanjutnya (Denney \& Tewksbury, 2013).

Studi literatur bisa didapat dari berbagai sumber baik jurnal, buku, dokumentasi, internet dan pustaka. Metode studi literatur adalah serangkaian kegiatan yang berkenaan dengan metode pengumpulan data pustaka, membaca dan mencatat, serta mengelolah bahan penulisan (Zed, 2008 dalam Nursalam, 2016).

Penelitian ini difokuskan untuk melihat bagaimana pengaruh kombinasi senam hipertensi dan slow deep breathing terhadap penurunan tekanan darah pasien hipertensi. Jenis penelitian yang digunakan adalah studi literatur atau studi kepustakaan (library research) yaitu mengumpulkan data yang didapat dari buku, jurnal atau karya tulis ilmiah yang berkaitan dengan obyek penelitian.

\section{HASIL PENELITIAN}

Berdasarkan hasil penelusuran di Google Schoolar dengan kata kunci hipertensi, senam hipertensi, slow deep breathing, gymnastic, dan lansia, peneliti menemukan 74.600 judul artikel yang sesuai dengan kata kunci. Artikel yang ditemukan sesuai dengan kata kunci tersebut belum semuanya memiliki tema yang sesuai dengan tujuan penelitian dan terdapat artikel yang duplikasi. Peneliti kemudian melakukan penelusuran menggunakan penelusuran lanjutan Google Schoolar dengan mencari kata kunci dalam judul (in title) yang sesuai kata kunci yang sama dengan penelusuran pertama dan ditemukan 5.630 artikel yang sesuai, kemudian 68.970 artikel yang tidak sesuai dengan tujuan penelitian dan artikel yang sama atau duplikasi dilakukan eksklusi.

Sebanyak 5.630 artikel yang ditemukan tersebut kemudian dilakukan skrining untuk melihat apakah artikel Jurnal Kesehatan dan Pembangunan, Vol. 11, No. 22, Juli 2021 
tersebut memiliki naskah lengkap atau tidak, selanjutnya 5.558 artikel kemudian dieksklusi karena tidak tersedia artikel full text dan berbayar sehingga didapatkan 72 artikel, kemudian diskrining kembali karena tidak sesuai kriteria penelitian, maka 62 artikel dieklusikan lagi, sehingga didapat hasil 14 jurnal . Artikel penelitian yang memiliki kemiripan tema / isi penelitian kemudian dipilih berdasarkan kriteria yang paling layak dan sesuai dengan tujuan penelitian

Berdasarkan hasil penelusuran di Google Schoolar dengan kata kunci hipertensi, senam hipertensi, slow deep breathing, gymnastic, dan lansia, peneliti menemukan 74.600 judul artikel yang sesuai dengan kata kunci. Artikel yang ditemukan sesuai dengan kata kunci tersebut belum semuanya memiliki tema yang sesuai dengan tujuan penelitian dan terdapat artikel yang duplikasi.

Peneliti kemudian melakukan penelusuran menggunakan penelusuran lanjutan Google Schoolar dengan mencari kata kunci dalam judul (in title) yang sesuai kata kunci yang sama dengan penelusuran pertama dan ditemukan 5.630 artikel yang sesuai, kemudian 68.970 artikel yang tidak sesuai dengan tujuan penelitian dan artikel yang sama atau duplikasi dilakukan eksklusi.

Sebanyak 5.630 artikel yang ditemukan tersebut kemudian dilakukan skrining untuk melihat apakah artikel tersebut memiliki naskah lengkap atau tidak, selanjutnya 5.558 artikel kemudian dieksklusi karena tidak tersedia artikel full text dan berbayar sehingga didapatkan 72 artikel, kemudian diskrining kembali karena tidak sesuai kriteria penelitian, maka 62 artikel dieklusikan lagi, sehingga didapat lah hasil 14 jurnal . Artikel penelitian yang memiliki kemiripan tema / isi penelitian kemudian dipilih berdasarkan kriteria yang paling layak dan sesuai dengan tujuan penelitian

Berdasarkan review jurnal sebagaimana dijabarkan dalam tabel 4.1. selanjutnya peneliti melakukan pengelompokan dan pemetaan data sebagai berikut :

\section{a. Desain penelitian.}

\begin{tabular}{llcc}
\hline No. & Desain penelitian & Jumlah & Persentase \\
\hline $1 . \quad \begin{array}{l}\text { Quasy experiment } \\
\text { dengan desain two } \\
\text { group pre-testpost- } \\
\text { test control design }\end{array}$ & 5 & $35,7 \%$ \\
\hline 2. & $\begin{array}{l}\text { Quasy Experiment } \\
\text { dengan desain Non } \\
\text { Equivalent Control } \\
\text { Group }\end{array}$ & 1 & $7,1 \%$ \\
\hline 3. & $\begin{array}{l}\text { kuantitatif pre } \\
\text { eksperimen dengan } \\
\text { rancangan pretest- } \\
\text { postest design }\end{array}$ & 3 & $21.5 \%$ \\
\hline 4. & & \\
& $\begin{array}{l}\text { quasi exsperimen } \\
\text { dengan pendekatan } \\
\text { one group pre tesi } \\
\text { and post test. }\end{array}$ & 5 & $35,7 \%$ \\
\hline & 14 & $100 \%$ \\
\hline
\end{tabular}

Sebagian besar desain penelitian yang direview adalah quasi exsperimen dengan pendekatan one group pre test and post test yaitu 37,5 \%. Quasy Experiment dengan desain Non Equivalent Control Group 7,1 \%. kuantitatif pre eksperimen dengan rancangan pretest-postest design $21.5 \%$. Quasy experiment dengan desain two group pre-testpost-test control design $35,7 \%$.

\section{b. Negara lokasi penelitian}




\begin{tabular}{clcc}
\hline No & Negara & Jumlah & Persentase \\
\hline 1. & Indonesia & 11 & $78,6 \%$ \\
\hline 2. & Thailand & 2 & $14,3 \%$ \\
\hline 3. & Ukraina & 1 & $7,1 \%$ \\
\hline
\end{tabular}

Tabel 4.3 negara lokasi penelitian yang direview

Negara lokasi yang banyak di review dalam penelitian ii aalah jurnal dari Indonesia yaitu 78,6 \%, kemudian dari negara luar ada Thailand sebanyak 14,3\% dan Ukraina 7,1\%.

\section{c. Artikel yang mengatakan senam dan slow deep breathing mampu menurunkan tekanan darah}

\begin{tabular}{l|l|c|} 
No & Artikel & Jumlah \\
1. & 14 artikel & $100 \%$
\end{tabular} \mid

Dari 14 artikel yang di review oleh peneliti, didapatkan bahwa senam dan slow deep breathing $100 \%$ dapat membantu menurunkan tekanan darah pasien hipertensi.

\section{PEMBAHASAN}

Pembahasan penelitian ini difokuskan pada hasil penelitian dari empat belas (14) artikel, 11 artikel berasal dari negara peneliti yaitu indonesia dan 3 artikel lain nya diambil dari artikel internasional. Dari 14 artikel yang sudah di review oleh peneliti, didapatkan hasil bahwa setelah dilakukan senam hipertensi dan slow deep breathing terdapat pengaruh terhadap penurunan tekanan darah pasien hipertensi.

\section{Menurut Susi (2017) Penyakit} hipertensi ini banyak dialami oleh lansia yang berumur 60 tahun keatas. Amin dkk
(2019) juga mengatakan hal yang sama bahwa kebanyakan yang menderita hipertensi adalah lansia yang berumur diatas 60 tahun. Tetapi hal ini tidak menjadi jaminan bahwa usia mudah akan terhindar dari penyakit hipertensi. Hal ini dijelaskan oleh Hernawan dkk (2017) bahwa penderita hipertensi dapat dialami oleh seseorang di usia 25 tahun keatas. Hipertensi tidak hanya terjadi di negara maju, tetapi negara berkembang juga terdapat banyak yang menderita hipertensi, hal ini sesuai dengan yang djelaskan oleh Sartika (2018) dan Amin (2019).

Penanganan hipertensi dapat dilakukan dengan pengobatan farmakologi maupun nonfarmakologi, sesuai dengan artikel Berek et.al (2015) yang mengatakan bahwa slow deep breathing dapat membantu menurunkan tekanan darah bagi pasien hipertensi, hal yang sama juga dikatakan Sartika (2018) bahwa senam lansia dapat membantu menurunkan tekanan darah pasien hipertensi jika dilkukan rutin oleh penderita hipertensi.

Berdasarkan hasil penelitian yang dilakukan Hernawan dkk (2017), dengan melakukan senam hipertensi dapat membantu menurunkan tekanan darah hipertensi. Hal ini sama dengan hasil penelitian oleh Tulak dkk (2017) yang dilaksanakan di Puskemas Wara Kota Palopo menunjukkan terdapat pengaruh senam lansia terhadap penurunan tekanan darah lansia dengan nilai $\mathrm{p}<0.05$ maka $\mathrm{Ha}$ diterima yang berarti ada pengaruh senam lansia terhadap penurunan tekanan darah lansia penderita hipertensi. Hal ini sejalan dengan hasil penelitian yang dilakukan oleh Najihah (2019) pasien yang rutin 
melakukan senam akan mengalami penurunan tekanan darah yang signifikan, begitulah pula penelitian yang dilakukan oleh Susi (2017) yang mengatakan bahwa dengan melakukan senam hipertensi dapat membantu menurunkan tekan darah baik sistol maupun diastol.

$$
\text { Selain senam, terapi }
$$

nonfarmakologi lain nya adalah slow deep breathing, Menurut penelitian Yanti dkk (2016) hasil penelitian tersebut dapat disimpulkan bahwa pemberian slow deep breathing dapat membantu menurunkan tekanan darah pada penderita hipertensi, ini juga sama yang disampaikan oleh Safitri dkk (2017) yang mengatakan bahwa dengan melakukan slow deep breathing secara rutin dapat menurunkan tekanan darah penderita hipertensi. Sangprasert (2018) juga mengatakan bahwa dengan melakukan slow breathing pasien hipertensi akan mengalami penurunan tekanan darah yang signifikan jika dilakukan secara rutin olh penderita hipertensi. Kemudian Rasyidah (2019) mengatakan bahwa hasil penelitiannya menunjukan bahwa slow deep breathing dapat membantu menurunkan tekanan darah penderita hipertensi jika dilakukan secara rutin oleh pasien hipertensi.

Dari beberapa artikel yang dibaca dan dipahami oleh penulis, didapatkan bahwa senam dan slow deep breathing dapat membantu menurunkan tekanan darah penderita hipertensi, hal ini sejalan dengan penelitian yang dilakukan oleh Meidilla (2017), Meidilla mengatakan bahwa hasil penelitian menunjukan senam dan slow deep breathing dapat menurunkan tekanan darah penderita hipertensi. Menurut penelitian yang dilakukan Amin dkk (2017), hasil penelitian menunjukkan bahwa tidak ada perbedaan efektivitas antara terapi slow deep breathing dan senam bugar lansia. Tekanan darah sistolik sesudah dilakukan terapi slow deep breathing dan senam bugar lansia $p$ value $=$ 0,136 dan tekanan darah diastolik $p$ value $=$ $0,716(<0,05)$. Kedua terapi tersebut terbukti dapat menurunkan tekanan darah pasien hipertensi.

\section{KESIMPULAN}

1. Terdapat 14 (empat belas) artikel yang memiliki relevansi dengan pengaruh senam hipertensi dan slow deep breathing terhadap penurunan tekanan darah pasien hipertensi.

2. Rata - rata dari 14 artikel mengatakan bahwa senam dan slow deep breathing dapat menurunkan tekanan darah penderita hipertensi jika dilakukan secara rutin oleh pasien hipertensi

3. Pada pasien hipertensi jika melakukan senam hipertensi dan slow deep breathing dapat membuat kualitas hidup menjadi baik dan dapat membantu menurunkan tekanan darah pasien hipertensi, dengan dilakukan secara rutin dan tetap menjaga pola makan, pola istirahat dan menghindari sesuatu yang akan membuat pasien menjadi stress.

\section{SARAN}

1. Diharapkan tenaga kesehatan khususnya perawat agar dapat menerapkan asuhan keperawatan dalam melakukan tindakan senam hipertensi dan latihan slow deep breathing untuk menurunkan tekanan darah pasien hipertensi.

2. Selain itu perawat juga diharapkan dapat memberikan penyuluhan kepada pasien tentang cara melakukan senam dan slow deep breathing yang bisa keluarga lakukan dirumah atau, klien sendiri yang melakukan nya jika bisa. 
3. Diharapkan dapat menambah pengetahuan mahasiswa mengenai teori tentang pengaruh kombinasi senam hipertensi dan slow deep breathing dalam membantu menurunkan tekanan darah pasien hipertensi.

\section{DAFTAR PUSTAKA}

Berek, et al., 2015. Effectiveness Of Slow Deep Breathing On Decreasing Blood Pressure In Primary Hypertension: A Randomized Controlled Trial Of Patients In Atambua, East Nusa Tenggara.

http://dx.doi.org/10.20319/mijst.2015.12 .0114

Dr.H.Masriadi,SKM.,S.Pd.I.,S.Kg.,M.Kes., MH.2016. Epidemiologi Penyakit Tidak Menular.TIM: Jakarta

Elysabeth, Dame et al., 2017. Slow Deep Breathing Reduces High Blood Pressure In Hypertensive Patients. https://www.researchgate.net/publicat ion/321938699

Hernawan, Totok \& Rosyid, Fahrun.2017. Pengaruh Senam Hipertensi Lansia Terhadap Penurunan Tekanan Darah Lansia Dengan Hipertensi Dipanti Werda Darma Bhakti Kelurahan Panjang Surakarta. Jurnal Kesehatan, ISSN 1979, Vol 10 No 1

Jones, et.al.2017. Slow Breathing Training Reduces Resting Blood Pressure and thePressure Responses to Exercise. https://doi.org/10.33549/physiolres.9 $\underline{32950}$

Kementerian Kesehatan RI (Kemenkes RI). 2013. Riset Kesehatan Dasar Tahun
2013.

Diakses melalui;//www.kemenkes.go.id//rikes das.doc.//pdf

Notoatmodjo, Soekidjo. 2012. Metode Penelitian Kesehatan. Jakarta: PT Rineka Cipta.

Nuramini, Susi. 2017. Pengaruh Slow Deep Breathing Dan Senam Lansia Terhadap Penurunan Tekanan Darah Lansia Penderita Hipertensi

Padila.2012.Buku Ajar Keperawatan Medikal Bedah.Nuha Medika: Yogyakarta

Potter, A.P.,\& Perry, A. 2006. Buku Ajar Fundamental Keperawatan Edisi 4 Volume 1. Jakarta : EGC

Rendy, M. Clevo \& TH Margareth.2012. Asuhan Keperawatan Medikal Bedah \& Penyakit Dalam.Nuha Medika.Yogyakarta

Riset Kesehatan Dasar (Riskesdas). 2013.Kemeterian Kesehatan RI, Badan Penelitian Dan Pengembangan Kesehatan Kementerian Kesehatan RI. Jakarta

Sangprasert. 2018. Preliminary study of Slow Deep Breathing in Mindfulness Exercise Effects on Physical Health Outcome among Hypertensive Patients.

www.bangkokmedjournal.com

So'emah et al.,2017. Effect Of Ergonomic Gymnastic To Lipid Profile And Blood Pressure In Patients With Hypertension At Sumber Agung Village Jatirejo District Mojokerto Regency. International Journal of Nursing and Midwifery 
Sugiyono.2016. Metode Penelitian

Kuantitatif, Kualitatif, dan $R \& D$.

Bandung: Alfabeta.

Sumartini, Ni Putu \& Miranti, Iham.2019.

Pengaruh Slow Deep Breathing

Terhadap Tekanan Darah Lansia

Hipertensi Di Puskesmas Ubung

Lombok Tengah. http://jkt.poltekkes-

mataram.ac.id/index.php.home/index

Tulak, Grace teddy \& Umar, Munawira.2017. Pengaruh Senam Lansia Terhadap Penurunan

Tekanan Darah Lansia Penderita Hipertensi.

www.journal.unismuh.ac.id/perspekti $\mathrm{f}$

World Health Organization (WHO). 2015.

Clinical Guiddelines For The

Managemennt Of Hypertension, Cairo:

World Health Organization. Yogyakarta

Werdhani, Retno Asti. 2007. Frekuensi Keteraturan Senam dan Penurunan Tekanan Darah Anggota Klub Jantung Sehat Pondalisa, Jakarta Tahun 2000 - 2005. Jurnal Kesehatan Masyarakat Nasional Vol. 1, No. 5, April 2007

Yanti.N.2016.Pengaruh Slow Deep Breathing Terhadap Tekanan Darah Pada Penderita Hipertensi Diwilayah Kerja Puskesmas I Denpasar Timur. Nurscope. Jurnal Keperawatan dan Pemikiran Ilmiah. 2(4).1-10 